\title{
Forum
}

\section{Blanket bans - conservation or imperialism? A response to Cooney \& Jepson}

\author{
Dilys Roe
}

The Wild Bird Declaration recently promoted by a coalition of conservation and animal welfare organizations seeks to ban all imports of wild birds into the EU. It recognizes that while not all bird species are necessarily rare or endangered, a blanket ban is the most effective way to reduce demand for all species (including those that are threatened), deter smuggling and facilitate enforcement. Cooney \& Jepson (2006) challenge each of these assumptions, arguing that while context-specific trade bans may have their uses, blanket bans have limited effectiveness and, moreover, may have unforeseen negative impacts on the livelihoods of poor communities. This is an issue that has recently been recognized by CITES Resolution Conf 8.3, noting that implementation of CITES-listing decisions should take into account potential impacts on the livelihoods of the poor'.

An issue that Cooney \& Jepson do not pick up on is the national governance implications of externally imposed trade bans. The Convention on Biological Diversity affirms that States 'have sovereign rights over their own biological resources'. Trade bans potentially undermine this sovereign right. The most common mechanism for controlling trade in wildlife is through CITES. By acceding to CITES, Parties agree to controls on international trade in species that are listed in one of the Convention's appendices, with Appendix I currently listing >800 animal and plant species. However, proposals to list species in the CITES Appendices or to move species between appendices can be submitted by any Party, whether or not that Party is a range state for the species concerned. A process of consultation with range states then occurs and acceptance of the proposal is dependent on it winning a two-thirds majority vote if there is no consensus position (Roe et al., 2002).

While each Party has one vote, it would not be accurate to say that each Party has the same voice because the size of delegations at Conferences of Parties and experience with the Convention processes can vary hugely. Northern countries can generally afford to send significantly larger delegations than developing countries, and to

Dilys Roe Natural Resources Group, International Institute for Environment and Development, 3 Endsleigh Street, London, WC1H ODD, UK.

E-mail dilys.roe@iied.org

Received 11 November 2005. Accepted 21 November 2005 commit ongoing resources to following and influencing the nuances of the Convention (at CoP 11 in Nairobi in 2000, for example, there were 35 delegates from the US compared to two from Burkina Faso, four from India and 11 from Zimbabwe; Roe et al., 2002).

Governance concerns, i.e. the right to decide how native wildlife may be used, including whether or not it may be exported, are particularly acute in the case of Appendix I listings. Jenkins (2000) draws attention to the difficulty and expense of downlisting a species compared to getting it listed in Appendix I in the first place. In cases where Appendix I listings are proposed by developed, non-range states, but where there is opposition from developing country range states this application of the Precautionary Principle can lead to high levels of frustration. Martin (2000) notes that "The voting system in CITES is unique in that it allows Parties who bear no financial costs for the protection of species which occur in other Parties' countries to, nevertheless, take decisions with financial implications for those range states'.

Despite its limitations, however, CITES is an agreement to which many countries (currently 169) have signed up. The Wild Bird Declaration calls for external imposition of stricter measures despite the existence of a functional, international agreement. Few would contest the right of range states to impose stronger measures in their domestic legislation to ban exports of native species where they consider trade in that species is not in the best interests of the country. Most countries had such bans in place for at least some native species prior to CITES coming into force in the 1970s (Roe et al., 2002). The right of one country or interest group to unilaterally ban imports from other countries is, however, more contentious, with the justification usually being the perceived failure of range states to maintain export volumes within sustainable levels. Given that the general direction of wildlife trade flows is from developing to developed countries, unilateral measures imposed by consumer countries, as well as undermining national sovereignty, can smack of Northern imperialism.

By effectively overriding what has been internationally agreed, stricter domestic measures can 'nullify the purpose for which states come together to form conventions' (Martin, 2000). Hutton (2000) makes the point more strongly, believing that 'there is no room for unilateralism in a multilateral environmental agreement 
that already requires participants to surrender some of their sovereignty'. Stricter domestic measures may also be subject to challenges under the World Trade Organization, a point made in a study on improving CITES effectiveness: 'While the adoption of stricter domestic measures is well recognized in international law, the application of this right has led to concerns over equity and raises questions over the compatibility of CITES with the GATT/WTO' (ERM, 1996).

Cooney \& Jepson also touch on the issue of bans in wild caught species stimulating captive breeding, and this is worth commenting on in the context of North-South equity. An example from Tanzania illustrates this point. The most highly traded of the parrot species during the 1980s, the small but colourful Fischer's lovebird Agapornis fischeri is endemic to Tanzania. Reported exports over 1983-1990 totalled c. 428,000 birds (Edwards \& Broad, 1992). Concern regarding the impacts of the trade on the species' wild populations prompted the implementation of a trade ban in 1995. As a result of the trade ban captive breeding proliferated and net exports from non-range states increased from $c$. 11,000 in 1991 to c. 95,000 in 1999, exceeding the peak exports recorded during a single year from Tanzania. China appears in CITES data as the main country of export in 1999 (nearly 74,000 birds), followed by South Africa (c. 12,000 birds). Tanzania, once the only country in which Fischer's lovebirds occurred and from which they could be supplied to foreign markets, lost all revenues resulting from the international trade of this species within a matter of years (Roe et al., 2002).

In some cases such ex situ production takes place within range states, for example in the case of many reptile species. In the majority of cases, however, the investment required to establish captive breeding facilities means that production generally moves to the consumer countries (i.e. developed countries). In the case of some CITES-listed bird species, for example, domestic captive breeding supplies a major proportion of the European and United States markets.

Fortunately for the proponents of the Wild Bird Declaration there is no longer any need to argue their case, at least in the short-term. In October 2005 bird flu was found in a parrot from Suriname that died while in British quarantine at Heathrow Airport. In response, the UK government called for a ban on wild bird imports to the EU and this was rapidly implemented. The EU ban covers 'captive live birds other than poultry imported for commercial purposes', and applies to imports from all countries (previously imports were only banned from countries that had bird flu cases, such as Romania, Thailand and Turkey). While estimates of imports of wild birds were as high as 2 million per year prior to the ban, EU states can now allow 'no more than five birds accompanying their owner to enter from third countries, on condition they have undergone a 30-day quarantine in approved third countries' (BBC, 2005). The ban is currently in place until the end of November after which time it will be reviewed, depending on the progress of the bird flu pandemic.

Conservation and animal welfare organizations are already lobbying for the ban to become permanent, with David Bowles of the RSPCA saying it was the right thing to do for 'welfare, conservation and disease control reasons' (BBC, 2005), although the link between bird flu and conservation or animal welfare is vague to say the least. Indeed the Australian Veterinary Association warns against a blanket ban, noting that it could provoke a resurgence in illegal trade and make the risk of a bird flu outbreak even greater (ABC, 2005).

Not only is the link between bird flu and conservation highly debatable, as Cooney \& Jepson point out, but the conservation case for any blanket ban on wild bird imports is not clear. It would be shame if the potential disaster of bird flu was used to mask a lack of sound conservation science, particularly where local livelihoods and North-South equity are threatened.

\section{References}

ABC (2005) Australian Veterinary Association warns against live bird import ban. $\mathrm{ABC}$ News, 21 October. Http://www.abc.net.au/pm/content/2005/s1488001.htm BBC (2005) EU bans imports of exotic birds. BBC News, 25 October. Http:/ /www.bbc.co.uk

Cooney, R. \& Jepson, P. (2006) The international wild bird trade: what's wrong with blanket bans? Oryx , 40, 18-23.

Edwards, S. \& Broad, S. (1992) Wild bird trade: perceptions and management in the Republic of Tanzania. In Perceptions, Conservation and Management of Wild Birds in Trade (eds J. Thomsen, S. Edwards \& T. Mulliken), pp. 131-150. TRAFFIC International, Cambridge, UK.

ERM (1996) Study on How to Improve the Effectiveness of CITES. Environmental Resources Management, London, UK.

Hutton, J.M. (2000) Who knows best? Controversy over unilateral stricter domestic measures. In Endangered Species, Threatened Convention. The Past, Present and Future of CITES (eds J.M. Hutton \& B. Dickson), pp. 57-66. Earthscan, London, UK.

Jenkins, R.W.G. (2000) The significant trade process: making Appendix II work. In Endangered Species, Threatened Convention. The Past, Present and Future of CITES (eds J.M. Hutton \& B. Dickson), pp. 47-56. Earthscan, London, UK.

Martin, R.B. (2000) When CITES works and when it does not. In Endangered Species, Threatened Convention. The Past, Present and Future of CITES (eds J.M. Hutton \& B. Dickson), pp. 29-37. Earthscan, London, UK.

Roe, D., Mulliken, T., Milledge, S., Mremi, J., Mosha, S. \& Grieg-Gran, M. (2002) Making a Killing or Making a Living? London, IIED \& IUCN, UK.

Wild Bird Declaration (2004) The European Union Wild Bird Declaration. An NGO Call to Halt Wild Bird Imports into the European Union. 223+ signatory organizations. Http:/ / www.worldparrottrust.org/trade/wildbirddec/wbdec.pdf [accessed 25 October 2005]. 